ordinary capacity for work. The picture of his last hours, which his sudden death, as with a flash-light, has photographed on the memory of his friends, is a true revelation of the man. The exacting demands of his position in the university and in the community about it did not exhaust either his interest or his energy. He was a watchful observer of all that went on in the world outside, of the movement of thought in literature and in politics; and his active mind sought frequent expression in reviews and other contributions to current periodicals. To the New York Nation, especially, for twenty-four years his contributions, on a great variety of topics, were almost as constant as the issues of the journal itself. $\mathrm{He}$ was intensely interested in men. For him no historical fact had any value 'except so far as it helps us to understand human nature, or the working of historic forces,' which have their root in human nature. As a teacher he felt a warm personal interest in his pupils; and they on their part are said to have been singularly drawn to him. Apart from his generous outgiving spirit, which placed his books, his learning, his advice freely at their service, there was something in the man that attracted them to him as to few other instructors, and established a bond of affection and respect that outlived the temporary relation of teacher and student, and often brought them back to him in later years for counsel and guidance. It is after all through this unrecorded influence on young men and women trained to be leaders in their several walks of life that his character and scholarship have sown their most fruitful seed.

\section{Clement Lawrence Smith.}

Harvard University.

\title{
PROFESSOR SELLAR, LL.D.
}

William Young Sellar, Professor of Humanity in the University of Edinburgh, whose work as an appreciative critic of Roman literature is increasingly valued by the reading world, died at his country residence of Kenbank, in Galloway, Scotland, on the 12th of October, 1890. His last illness, jaundice, arising from a chill, was short and sharp. But it is consolatory to think that throughout the preceding summer he had been in better health than for some years previously, and had had much enjoyment in his work and in the society of intimate friends. A tour in Italy, made soon after the conclusion of the winter session, in which he visited the haunts of favourite Latin poets, had seemed to revive him and to restore his strength.

An estimate of his contributions to the literature of scholarship must be reserved for some more competent hand, and were it not an impertinence on my part there is not time for it now. But a brief outline of his uneventful life from one whose acquaintance with him dates from thirty-five years ago may not be unwelcome to those who have been interested by his writings.

At an early age he was sent from his northern home in Sutherlandshire to compete with those who were two or three years his seniors as a pupil of the Edinburgh Academy, then at the height of its renown as a classical seminary and threatening to supplant the ancient High School. Under strict and somewhat stern surveillance, with the single motive of excelling to please his father, be kept steadily at the top of his class, until at fourteen he carried off the 'dux medal' from the whole school. Of those seven years of schooling he always retained many genial and humorous memories, but on the whole he looked back upon them as a time of gloom, in which the affections were starved and the intellect prematurely forced. $\mathrm{He}$ used himself to trace some of the liability to illness which haunted him in later life to that early pressure. But on the other hand there can be no doubt that to the extreme accuracy of Andrew Carmichael and to the great teaching powers of the rector, Archdeacon Williams (he had been the nominee of John Lockhart and Sir Walter Scott), Sellar owed the solid and lasting foundation of the ripe scholarship which he afterwards displayed.

From the Academy young Sellar proceeded to the University of Glasgow, where he continued to distinguish himself, and at seventeen was appointed Snell Exhibitioner to Balliol College, a position which had previously been held by Archibald Tait (since Archbishop of Canterbury), and Sir William Hamilton, the metaphysician. But following the native instinct and the paternal wish, 


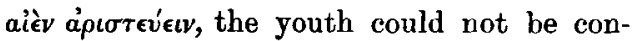
tented without obtaining "the blue ribbun of English scholarship,' and he was a winner of the Balliol Scholarship in 1843.

When he went to Glasgow, Edmund Lushington had recently succeeded Sir Daniel Sandford as Professor of Greek. And one of those abiding admirations which never waned nor wearied was awakened in Sellar's mind by the inaugural lecture on Greek literature, in which the young Cambridge scholar of twenty-five exhibited a maturity and comprehensiveness of judgment only equalled by the rich gracefulness and noble dignity of the style.

The Chair of Latin had been held for some years by Professor William Ramsaybest known perhaps for his Roman Antiquities, but deserving credit also for other lasting contributions to learning. He was at that time deeply engaged with original work for Dr. Smith's Dictionaries of Classical Antiquities and Classical Biography, which were published severally in 1842 and 1843 . Ramsay's influence, as will be seen presently, is a factor not to be ignored in studying the formation of Sellar's mind. His friendship with both these teachers and their families was life-long; and he was also at Glasgow brought into close relations with Norman Macleod, which led to a friendship with him and his that was maintained until the end. And to the end continued also another friendship which originated in the transition from Glasgow to Uxford. To prepare for Balliol, he went, probably by Professor Lushington's advice, to Mr. William Dobson, who had been third Classic in Lushington's and Thompson of 'Trinity's year, and was for many years at the head of Cheltenham College. He spent some months of great enjoyment in that quiet household.

At Balliol he found companionships such as heretofore he can have hardly known. The Balliol scholars of that date have been celebrated by the late Principal Shairp in one of the best known of his poems. There was Arthur Hugh Clough, there was Matthew Arnold, there was Robert Morier, there was Shairp himself, there were Grant and Sandars, and others destined along with Sellar to be Fellows of Oriel. There, too, it must never be forgotten, not as scholar but as fellow, was one hardly removed from boyhood, but already plying eagerly that elder brother's part which has won him reverence from so many generations of Oxford men-he of whom Sellar used to speak to his mother (as she herself once told the present writer) as 'the divine Jowett.'
It was now more than ever previously that there was developed in him the passion for companionship which never left him. Now too, about the time of his first-class degree, he began to feel some reaction from the long previous strain. An inequality of health and spirits, ending with a period of pronounced illness, gave some anxiety to his friends. He went to Malvern, where the hydropathic treatment was in full activity, but neither then nor afterwards was led to a belief in watercures. The real cure was found in regular and not too severe occupation. After gaining the Oriel Fellowship in 1850, he taught for a while in the young University of Durham, but was called away in the following year to assist his friend Professor William Ramsay, who had broken down in health. Two years thus spent in Glasgow were among the most eventful in his life. For they led the way to a result most fruitful in after happiness-his marriage to Miss Eleanor M. Dennistoun. Nor can it be supposed that the renewal of intercourse with his former teachers was without effect on his intellectual growth. The speculations of young Oxford in those days, when the Tractarian party were losing hold, and neither the Broad-Church nor the Positivist nor the Socialist movement had yet begun, were apt to be, if wide-sweeping, yet somewhat vague. That could not be said of Lushington's Inaugural, nor of Ramsay's articles 'Agricultura,' ' Cicero,' 'Juvenalis,' 'Lucilius,' 'Lucretius.' It can hardly have been accidental that in his years at St. Andrews, first as Assistant to the Professor of Greek (1853-1859), and afterwards (1859-1863) as Professor, he should have applied his well-proved powers of thought and of composition to similar themes. His essays on 'Lucretius' (Oxford Essays, 1855), and on the "Characteristics of Thucydides' (Oxford Essays, 1857), were the first-fruits of these special studies. Then; shortly before he became a candidate for the Chair of Humanity in Edinburgh", there appeared his tirst substantial volume, The Roman Poets of the Republic.

A pleasing testimony to Sellar's influence as a teacher at St. Andrews is given by Mr. Andrew Lang in a contribution to a fugitive publication called Alma Mater's Mirror (Edinburgh, 1887). He had then and always the power of interesting his pupils even more in the literature than in the minutiae of the language, which a schoiar of Andrew Carmichael's was, however, in no danger of neglecting. He was also famous for maintaining order. ' $\mathrm{He}$ has been over the 
ground before you to make it smooth, like a great roller,' said Mrs. Ferrier to his successor in the Greek Chair. 'You will find them in good training, like a set of young pointers' was his own expression.

Apart from duties which were not felt as heavy, Mr. and Mrs. Sellar at St. Andrews were the life of a society that was otherwise not wanting in living powers. The Ferriers, the Shairps, the Tullochs, James D. Forbes and his family, Professor and Mrs. Veitch and others, lived together there on terms of close intimacy and cordial friendliness. And in those years Sellar began the practice which he continued afterwards of making the acquaintance of young scholars and opening his house to them. I myself was a happy guest at Abbey Park in 1855. It was something of a wrench to him to leave St. Andrews. A lover of games and of the open air, he was devoted to golf, which he enjoyed none the less for not being a firstclass player. And the familiar coterie was more congenial to his tastes than a larger and less intimate society. His acute conscientiousness also shrank a little from the great increase of responsiblity involved in the change. How he fulfilled the charge now committed to him through the loug tenure of twenty-seven years is matter of notoriety. His pupils, with their high academical distinctions and, in more than one case, successful authorship, witness silently, as they will no doubt witness loudly, to the fact.

Companionship was as the breath of life to Sellar. And it was in close companionship that his entire freedom from anything approaching to envy, his genial humour, so often directed against himself, his true modesty and his high and delicate sense of personal honour, were most conspicuously felt. $\mathrm{H}_{\mathrm{e}}$ had the sincerity of genius and, if such a thing is possible, he might be called candid to a fault.
The loss of friends was the most real of losses to him. And as men so different from each other yet so allied to him as Henry Lancaster, Sir Alexander Grant, and John Campbell Shairp-the first two suddenlypassed one by one into the silent world, a portion of his own vitality seems to have ebbed away from him. Last of all came the loss of his younger brother Alexander, in whose public career he had taken such justifiable pride, and with whom he had constantly communicated his thoughts, especially on things political; - this was a blow from which he never entirely recovered. Against the loss, however, it is right to set the gain. In some of his travels he had the fellowship of Professor George Ramsay, in others that of Mr. Alfred Benn; and he had I think made the acquaintance of Comparetti, whose works he greatly valued. Sir Charles Bowen's translation of Virgil had pleasantly renewed a former intimacy, and I trust I may not intrude too far on personal matters if $I$ allude to the comfort which he had in his later years from his colleague in the Edin burgh Chair of Greek, with whom he found himself in perfect sympathy, and to whom he characteristically looked up with admiration. Professor Butcher has the rare happiness,

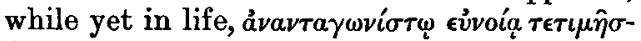
$\theta$ ac.

The book on Virgil, the first instalment of The Poets of the Augustan Age, was published in 1877 and, together with The Roman Poets of the Republic, has been for some time in a second edition.

In conclusion, let me repeat the hope which has been expressed by an eminent scholar, whom Sellar was one of the first to estimate at his true worth, that the studies on Horace, Ovid, Propertius and other Latin poets on which Professor Sellar was latterly engaged may be found to be in a sufficiently advanced state for early publication.

\section{Lewis Campbell.}

\section{ARCHAEOLOGY.}

Mythology and Monuments of Ancient Athens ; being a translation of a portion of the 'Attica' of Pausanias by Margaret de G. VerRaLL, with introductory essay and archaeological commentary by JANE E. Harrison. London, Macmillan and Co. 1890. $16 s$.

THIs is a valuable book, and one of a novel sort. It has been sometimes spoken of as if it belonged to the class represented by Dyer's Anciert Athens, but Miss Harrison bas been careful to explain in her preface that topography and monuments have, for her, only a subordinate importance. Her " aim has been to discuss in full detail every topographical point that could bear upon mythology, and, for the sake of completeness, to touch, but very briefly, on such non-mythological monuments as were either noted by Pausanias 